\title{
Students' Perception on the Usefulness of ICT-Based Language Program
}

\author{
Wiyaka $^{1}$, Januarius Mujiyanto ${ }^{2} \&$ Dwi Rukmini ${ }^{2}$ \\ ${ }^{1}$ English Department, Universitas PGRI Semarang, Indonesia \\ ${ }^{2}$ English Department, Faculty of Languages and Arts, Universitas Negeri Semarang, Indonesia \\ Correspondence: Wiyaka, English Education Department, Universitas PGRI Semarang, Jalan Sidodadi Timur 24 \\ Semarang, Indonesia. Tel: 62-8232-3750-657. E-mail: wiyaka@upgris.ac.id
}

Received: October 29, 2017 Accepted: January 6, 2018 Online Published: January 9, 2018

doi: 10.5539/elt.v11n2p53 URL: http://doi.org/10.5539/elt.v11n2p53

\begin{abstract}
This paper presents the result of a survey on the usefulness of an ICT-based software program called DEC (a pseudonym for a particular commercial English learning resource). This program was utilized by English Departement University of PGRI Semarang as a complementary software in Integrated Course offered to the first semester students. The research adopted Technology Acceptance Model (TAM) by Davis (1989) which focused on the perceived acceptability of the program. An online questionaire was used to get the data. 236 students participated in the survey. The collected data were tabulated and interpreted descriptively. The findings show various results from the questionnaire under the 4 headings: perceived ease of use, perceived usefulness, perceived attitude towards usage, and perceived intentional behavior to use.
\end{abstract}

Keywords: ICT, Integrated course, TAM

\section{Introduction}

Today the growing reliance on the use of computers is inevitable. Computers have been utilized in a vast areas of modern people's life such as business, entertainment, education, and others. In daily context, the use of computers is known as ICT which stands for information and computer technology. In education, changing methods of learning and rapid growth of computer technology have brought about the new trends of language teaching and learning. Language classrooms are increasingly turning into blended learning environments that focus on active learning. It is commonly known that active learning advances the learning process and thus enhances the quality of the language learning experience (Kumar \& Tammelin, 2002). Blended language learning applies some teaching and tutoring methods by combining real classroom setting with online activities and using a mix of technology-based materials. The growing demand for ICT use in blended language learning settings has turned the model of language teaching and learning in a beneficial way and will go on to do so along with future technological advances. According to Jonassen et al. (1999), the main benefit of ICT to language learning is that it can make meaningful learning as active, authentic and cooperative.

ICT can be applied in some ways in language courses. On-campus language courses can be supplemented with course websites and online interactions. There are also courses that combine classroom teaching with online modules and activities can be provided (blended learning courses). Courses can be provided completely online with no classroom-based component (online courses). Another mode of ICT language program is virtual learning environments that can be applied for foreign language learning purposes. The different ways of using ICT listed above are not mutually exclusive and can be combined depending on the needs and the environment of each institution.

Kumar and Tammelin (2002) assert that the decisions to take course design count on the type of course offerings planned by an institution. When determining to apply ICT institution-wide or at varying degrees in different subject matter areas, it is important to consider whether the proposed integration of ICT, for example online offerings, negatively impact or positively supplement existing degree or diploma programs. In many educational institutions, certain departments, teachers, faculty, or subject matter may exist to be more conducive to the introduction of ICT. Institutions often pilot ICT implementation in one subject area, learn from the results, and then extend it to other subjects taught by the institution. 
Together with the trend of increasing ICT integration into teaching and learning around the world, University of PGRI Semarang is challenged to prepare teacher candidates with sufficient skill in implementing or using ICT. It becomes more urgent for student teachers of English because more access on the internet will facilitate the teaching learning process. A course of ICT with two credits is made obligatory to be attended by all students. Besides that, the lecturers are also encouranged to use the facilities of internet or campus web site to improve the quality of teaching. English department, beginning from the 2013 academic year has applied a kind of Computer Assisted Language Learning (CALL) with internet-based learning of DEC program.

DEC offers a unique framework for blended learning that optimizes the use of technology. DEC specializes in English. It has by far the largest range of content available for English language learning, and has fifteen different titles, each specifically prepared for a certain age group, language level and type of language needed. It is blended language learning system combining the best features of traditional learning and contemporary multimedia technology. Students benefit from teacher-led studies followed by computer-based self-study work either online or offline - all designed to optimize the learning process.

Such a program has been used by several institutions in Indonesia, and English Department University of PGRI Semarang is one of them. This program has been running in one semester in Intergrated Course (IC) for the freshman level, and it needs feedback for evaluation, either from the students or the instructors/the lecturers. This study is a kind of evaluation on using the software from the students's perception.

\subsection{Importance of the Problem}

The current study was conducted due to various considerations. First, in the university there has been no research yet to investigate the students' behavioural intention to use DEC courseware. The findings of this study would also be used to provide the university with evaluation on the use of ICT-based courses. Further, this study will pave the way for future research on technology acceptance, more specifically on the effect of one variable to another which has not been detected in this research. Lastly, this study adopted and modified a questionnaire to suit the acceptance of context that may be reused in future research.

\subsection{Relevant Scholarship}

Combining ICT in the process of education, particularly education for student teachers, is undeniable as they should learn and then teach their students later how to cope with a society in which virtual communication media force them to struggle with different kinds of cultures and values. This becomes urgent for student teachers of EFL as they will encounter situation in which English and ICT is badly needed in learning. The use of computer may lessen the teacher presence in the classroom. Students can access the materials by themselves and the teacher is only to facilitate the learning. The growing need for competence-based curriculum also drives the use of computer technology as a method of modern learning which facilitates the learners to access knowledge and information anytime and anywhere. The utilization of internet and computer networks has changed the nature of education from teaching to learning. It is the students who learn, not the teachers who teach, as the focus of education.

Academic research and literature have reported extensive benefits of using ICT in language teaching and learning. Some scholars have conducted research on the use of ICT in education field. Heidari et al. (2010) as quoted in Zanjan and Ramazani (2012) conducted a research to compare the effect of teaching English with educational software and conventional method on progress of learners. The result of the study revealed that not only is the use of educational software in teaching useful, but also the effect of it on progress of learners is better than conventional method. It was also revealed that English teaching by using educational software is effective to promote learners' motivation in learning.

A similar result was found from a research by Almekhalafi, 2006 on the effect of language learning with the aid of computer on progress and motivation of primary school students as a foreign language in United Arab Emirates. The research subjects involved 83 students which consisted of the experiment group and the control group. The control group was taught English without using computer and the experiment group was taught by using computer. It was revealed that there was a considerable difference between the two groups leaving the benefit to the experiment group. Besides, it was also revealed that the experiment group had more motivation to learn English than the control group.

Another study was conducted by Chuan K. S., and Chou, T. W. in 2002 on the effect of internet networks on learning various parts of English language such as conversation, comprehension, writing, intonation and grammatical structures. He found out that using internet networks can improve students' learning in various language skills and competencies. While in 2001, Kendrasue did a similar research on the effect of computer 
software on learning English course, and he concluded that such facilities can enhance the result of English language learning. The result of the study showed that word processing in computer allows a student to say what he wants, has focus, without being slow or frustrated in writing, deleting and correcting or searching words in a dictionary. It was also revealed that different types of dictionaries make a student have complete access to words and their meanings and this in turn is a great advantage in learning meanings of words and phrases.

A study by Oliver in 2002 found that ICTs have impacted on educational practice in education in at least four areas: what is learned, how it is learned, when and where learning takes place and who is learning and who is teaching. He concluded that the impact will grow considerably in years to come and that ICT will become a strong agent for change among many educational practices.

The above samples are just a few. Overall, the result of any study on it has shown the importance of integrating ICT in a language program. However, in spite of the benefits of ICT, there still exist barriers to effective integration of ICT into language teaching. External challenges such as lack of ICT access, equipment, and training as well as some internal ones such as teachers' and students' beliefs and attitudes towards ICT use in teaching and learning may hinder the application of ICT in language teaching. This study was intended to reveal the students' perception on the usability of ICT in language course.

\section{Method}

\subsection{Participants}

The study was conducted at the English Education department of University of PGRI Semarang. It involved all student teachers enrolled in the Bachelor of Education English Language Program of Batch 2015/2016. The total number of participants was 236. They were students who attended the Integrated Course (IC) in the first semester of the program of which 4 credit units were given to the IC. The course content was adopted from the DEC. Using this courseware, the students were allowed to practice all the four language skills in multimedia format. The students had to demonstrate the advancement and development of their individual competencies/skills, achievement, and learning during the courses in one semester.

\subsection{Instrumentation}

The research instrument consists of a questionnaire using 5-point Likert response scale where 5: Strongly agree, 4: Agree, 3: Neutral, 2: Disagree, and 1: Strongly Disagree. The items of questionnaire are adapted from the technology acceptance model (TAM) constructs (Davis, 1989) with little modification as it excludes the external factors such as the availability of the internet access, and the support from the administration. TAM is possibly the most widely-used framework for measuring technology acceptance, and its high validity has been proven empirically in many previous studies (Alharbi, Saleh, \& Drew, Steve 2014). The TAM construct of the items can be seen at Table 1 below.

As shown in Table 1, there are 18 items measured in accordance with the current study's research model. The measured items include perceived ease of use (7 items), perceived usefulness (6 items), attitude toward usage (3 items), and behavioural intention to use ( 2 items). To ensure the clarity, the questionnaire was also translated into Bahasa Indonesia, the students' mother tongue language.

Table 1. Questionnaire

\begin{tabular}{|c|c|}
\hline Section I & Perceived Ease of Use (PEU) \\
\hline I feel that using a DEC would be easy for me & PEU1 \\
\hline I feel that my interaction with DEC would be clear and understandable & PEU2 \\
\hline I feel that it would be easy to become skillful at using DEC & PEU3 \\
\hline I would find DEC to be flexible to interact with & PEU4 \\
\hline Learning to operate DEC would be easy for me & PEU5 \\
\hline It would be easy for me to get DEC to do what I want to do & PEU6 \\
\hline $\begin{array}{l}\text { I feel that my ability to determine DEC ease of use is limited by my lack of } \\
\text { experience }\end{array}$ & PEU7 \\
\hline Section II & Usefulness (PU) \\
\hline Using DEC in my job would enable me to accomplish tasks more quickly & PU1 \\
\hline Using DEC would improve my job performance. & PU2 \\
\hline
\end{tabular}




\begin{tabular}{|c|c|}
\hline using DEC in my job would increase my productivity & PU3 \\
\hline Using DEC would enhance my effectiveness on the job. & PU4 \\
\hline Using DEC would make it easier to do my job & PU5 \\
\hline I would find DEC useful in my job & PU6 \\
\hline Section III & Attitude Toward Usage (ATU) \\
\hline I believe it is a good idea to use a DEC & ATU1 \\
\hline I like the idea of using a DEC & ATU2 \\
\hline Using a DEC is a positive idea & ATU3 \\
\hline Section IV & $\begin{array}{l}\text { Behavioral Intention to Use } \\
\text { (BIU) }\end{array}$ \\
\hline I plan to use a DEC in the future & BIU1 \\
\hline Assuming that I have access to a DEC, I intend to use it & BIU2 \\
\hline
\end{tabular}

Note: $\mathrm{DEC}=$ a trade mark of commercial ICT-based English language learning.

\subsection{Data Collection}

During the class session at the end of term participants were told to take part in responding to the questionnaire. The questionnaire did not distinguish females from males because the current research did not count these variables. As I have mentioned earlier the goal of this study is to find out the students perception on the usefulness of the ICT-based English course. The data were colleted through an online survey. The questionnaire consisting 18 items was put on a website provided by survey monkey with the address http;//www.surveymonkey.com/s/Q2TYDJZ. We put an announcement on the board and by facebook facility, informing a call for all attendants of IC to fill out the online questionnaire. Upto the end of December 2015 there were 236 responses collected from the 310 of the population.

\subsection{Method of Data Analysis}

The research was a descriptive-survey. The method of descriptive statistics in terms of percentage has been employed for data processing and the method of deduction has been employed to analyze and interpret data.

\section{Results and Discussion}

The findings of the survey are presented on the basis of each item in the questionnaire. Since there are 4 categories of the items, the collected data will be presented under the heading of category in the following section and followed by the description.

\subsection{Perceived Ease of Use (PEOU)}

Perceived ease of use is defined as "the degree to which the prospective user expects the target system to be free of effort" (Davis, 1989). In this study, perceived ease of use is defined as the degree to which the students believes that learning to use an DEC requires a relatively low degree of effort. It implies that the tool of ICT which is applied should make the learning simple. The following table presents the students' response.

Table 2. Perceived Ease of Use (PEOU)

\begin{tabular}{|c|c|c|c|c|c|c|c|}
\hline \multirow[b]{2}{*}{ No } & \multirow[b]{2}{*}{ Item } & \multicolumn{5}{|l|}{ Criteria } & \multirow[b]{2}{*}{ total } \\
\hline & & $\begin{array}{l}\text { Strongly } \\
\text { agree }\end{array}$ & Agree & Neutral & Disagree & $\begin{array}{l}\text { Strongly } \\
\text { disagree }\end{array}$ & \\
\hline 1 & $\begin{array}{l}\text { I feel that using a DEC } \\
\text { would be easy for me }\end{array}$ & 66 & 88 & 44 & 23 & 15 & 236 \\
\hline 2 & $\begin{array}{l}\text { I feel that my interaction } \\
\text { with DEC would be clear } \\
\text { and understandable }\end{array}$ & 56 & 85 & 52 & 32 & 11 & 236 \\
\hline 3 & $\begin{array}{l}\text { I feel that it would be easy to } \\
\text { become skillful at using } \\
\text { DEC }\end{array}$ & 48 & 64 & 66 & 40 & 18 & 236 \\
\hline
\end{tabular}




\begin{tabular}{|c|c|c|c|c|c|c|c|}
\hline 4 & $\begin{array}{l}\text { I would find DEC to be } \\
\text { flexible to interact with }\end{array}$ & 67 & 76 & 45 & 33 & 15 & 236 \\
\hline 5 & $\begin{array}{l}\text { Learning to operate DEC } \\
\text { would be easy for me }\end{array}$ & 43 & 47 & 85 & 43 & 18 & 236 \\
\hline 6 & $\begin{array}{l}\text { It would be easy for me to } \\
\text { get DEC to do what I want to } \\
\text { do }\end{array}$ & 48 & 78 & 50 & 26 & 34 & 236 \\
\hline \multirow[t]{3}{*}{7} & $\begin{array}{l}\text { I feel that my ability to } \\
\text { determine DEC ease of use } \\
\text { is limited by my lack of } \\
\text { experience }\end{array}$ & 47 & 66 & 62 & 33 & 28 & 236 \\
\hline & total & 375 & 504 & 404 & 230 & 139 & \\
\hline & Percentage & $23 \%$ & $31 \%$ & $24 \%$ & $14 \%$ & $8 \%$ & $100 \%$ \\
\hline
\end{tabular}

From the above table we can infer that the DEC seems not easy for students to operate. When combined together, there are only $54 \%$ of students perceived that the courseware is easy to use. Even from item 5 we can see that only 43 of 236 admitted that the courseware is easy to operate. From the table we can also infer that $22 \%$ of the respondents found the DEC too difficult to use, despite the fact that they had attended training workshops from the lecturer. Practicality and simplicity of the tool or the software is of important consideration for the students. It is understandable since students usually avoid programs which are difficult to operate. Any particular program is preferred when it would be free of effort. The software program must be free from difficulty or great effort. Effort is a finite resource that a person may allocate to the various activities for which he or she is responsible (Radner \& Rothschild, 1975). All else being equal, we claim, an application perceived to be easier to use than another is more likely to be accepted by users.

\subsection{Perceived Usefulness (PU)}

Davis (1989) defined perceived usefulness as "the prospective user's subjective probability that using a specific application system will increase his or her job performance within an organizational context". In this study, perceived usefulness is defined as the degree to which the student teachers of the English Department of University of PGRI Semarang believe that using DEC would enhance his or her job performance. The table below presents the data of students' perceived usefulness

Table 3. Students' Perceived Usefulness (PU)

\begin{tabular}{|c|c|c|c|c|c|c|c|}
\hline \multirow[b]{2}{*}{ No } & \multirow[b]{2}{*}{ Item } & \multicolumn{5}{|l|}{ Criteria } & \multirow[b]{2}{*}{ total } \\
\hline & & $\begin{array}{l}\text { Strongly } \\
\text { agree }\end{array}$ & Agree & Neutral & Disagree & $\begin{array}{l}\text { Strongly } \\
\text { disagree }\end{array}$ & \\
\hline 1 & $\begin{array}{l}\text { Using DEC in my job would } \\
\text { enable me to accomplish } \\
\text { tasks more quickly }\end{array}$ & 52 & 78 & 40 & 38 & 28 & 236 \\
\hline 2 & $\begin{array}{l}\text { Using DEC would improve } \\
\text { my job performance }\end{array}$ & 67 & 61 & 44 & 42 & 22 & 236 \\
\hline 3 & $\begin{array}{l}\text { Using DEC in my job would } \\
\text { increase my productivity }\end{array}$ & 53 & 63 & 52 & 35 & 33 & 236 \\
\hline 4 & $\begin{array}{l}\text { Using DEC would enhance } \\
\text { my effectiveness on the job }\end{array}$ & 62 & 55 & 54 & 33 & 32 & 236 \\
\hline 5 & $\begin{array}{l}\text { Using DEC would make it } \\
\text { easier to do my job }\end{array}$ & 87 & 77 & 35 & 18 & 19 & 236 \\
\hline \multirow[t]{3}{*}{6} & $\begin{array}{l}\text { I would find DEC useful in } \\
\text { my job }\end{array}$ & 51 & 78 & 34 & 39 & 34 & 236 \\
\hline & total & 372 & 412 & 259 & 205 & 168 & \\
\hline & Percentage & $26 \%$ & $29 \%$ & $18 \%$ & $14 \%$ & $12 \%$ & $100 \%$ \\
\hline
\end{tabular}


Again, perceived usefulness here is defined as "the degree to which a person believes that using DynEd would enhance students' job performance. It is clear from the table that not all students perceived that the DynEd is useful to accomplish their jobs. $26 \%$ of respondents thought that the courseware would not enhance their jobs. Only $55 \%$ of students surely believe that the program could improve their performance. It must be an important warning to the producer of the program to seek the causes of such a perception. A tool will be used when it brings about improvement in the job performance. In other words, people will use a tool when it is useful for their jobs. A program has high perceived usefulness when the user believes in the existence of a positive use-performance relationship ((Ajzen \& Fishbein, 2000).

\subsection{Attitude towards Usage (ATU)}

ATU represents individuals' evaluative feelings (positive or negative) when performing a particular behavior (Ajzen \& Fishbein, 2000). Attitude towards the usage will determine the intention to use a certain program or learning tool. The students' attitude towards the DEC can be seen in table 4 below.

Table 4. Students' Attitude towards Usage (ATU)

\begin{tabular}{llllllll}
\hline \multirow{2}{*}{ No } & Item & \multicolumn{2}{l}{ Criteria } & & & \\
\cline { 3 - 6 } & & $\begin{array}{l}\text { Strongly } \\
\text { agree }\end{array}$ & Agree & Neutral & Disagree & $\begin{array}{l}\text { Strongly } \\
\text { disagree }\end{array}$ & \\
\hline 1 & I believe it is a good idea to use a DEC & 56 & 65 & 56 & 28 & 31 & 236 \\
2 & I like the idea of using a DEC & 62 & 59 & 45 & 37 & 33 & 236 \\
3 & Using a DEC is a positive idea & 77 & 86 & 36 & 14 & 23 & 236 \\
& Total & 195 & 210 & 137 & 79 & 87 & \\
& Percentage & $28 \%$ & $30 \%$ & $19 \%$ & $11 \%$ & $12 \%$ & $100 \%$ \\
\hline
\end{tabular}

It can be identified from the table that $58 \%$ of respondents have positive attitude towards the usage of DEC course while $19 \%$ do not have ideas about the program, and $23 \%$ have negative attitude. This again should become reminder for the lecturer as well as the designer of the DEC product to revise the program or the product. A program should ideally present good and positive impression to the users. When more than 20 per cent of the users complain the product, there must be direct review from the designer of to improve the product. This attitude has been identified as a factor that guides future behavior and as an intentional cause that ultimately leads to a particular behavior.

\subsection{Users' Behavioral Intention to Use (BIU) the Program}

Behavioral intention (BI) is defined the actual use of a given program and therefore determines technology acceptance. This is similar to a drive to apply or use the program. The following table represents the students' intention to use the DEC.

Table 5. Users' Behavioral Intention to Use (BIU) the Program

\begin{tabular}{llllllll}
\hline & & \multicolumn{3}{l}{ Criteria } & & & \\
\cline { 3 - 6 } No Item & $\begin{array}{l}\text { Stron } \\
\text { gly } \\
\text { agree }\end{array}$ & $\begin{array}{l}\text { Agre } \\
\text { e }\end{array}$ & $\begin{array}{l}\text { Neutr } \\
\text { al }\end{array}$ & $\begin{array}{l}\text { Disag } \\
\text { ree }\end{array}$ & $\begin{array}{l}\text { Strongl } \\
\text { disagre } \\
\text { e }\end{array}$ & total \\
\hline 1 & $\begin{array}{l}\text { I plan to use a DEC in the future } \\
\text { Assuming that I have access }\end{array}$ & 77 & 67 & 45 & 25 & 22 & 236 \\
& $\begin{array}{l}\text { DEC , I intend to use it } \\
\text { Dotal }\end{array}$ & 56 & 85 & 52 & 32 & 11 & 236 \\
& $\begin{array}{l}\text { Total } \\
\text { Percentage }\end{array}$ & 133 & 152 & 97 & 57 & 33 & \\
\hline
\end{tabular}

It can be inferred from the table that $60 \%$ of the students plan to use the same program, while $21 \%$ have not decided yet, and $19 \%$ do not intend to use the same program. It has been identified that there are factors that 
guide future intention. One's attitude towards the program will ultimately lead to a particular behavior. According to the model, a user's intention is affected by the attitude towards the system. A user's perceptions of a system's usefulness and ease-of-use result in a behavioural intention to use (BIU), or not to use, the system (Davis, Bagozzi, \& Warshaw, 1989).

\section{Conclusion}

This survey research revealed that students have different perception on the use of ICT-based DEC program offered to them. The result of the survey can be summarized below.

1) The results indicate some positive perception on the ease of use of ICT-based learning by the students of English department. There are only $54 \%$ of students who perceived that the courseware is easy to use. $22 \%$ of the respondents found the DEC too difficult to use. This shows the low ease of technology use which is relevant to E-Learning so that it could not facilitate English language learning.

2) In relation to usefulness, the result indicates that $55 \%$ of students surely believe that the program could improve their performance while $26 \%$ of respondents thought that the courseware would not enhance their jobs. The result indicates the unsatisfactory usefulness of the program from the students perspective.

3) In relation to the attitude, the survey indicates that $58 \%$ of respondents have positive attitude towards the usage of the DEC while $19 \%$ do not have ideas about the program, and $23 \%$ have negative attitude. The so large percentage of the students who have negative evaluation to the program signals the incorrect application of the software. This needs further investigation.

4) The survey also tells us that $60 \%$ of the respondents plan to use the software of DEC in the future, while around $20 \%$ do not intend to use the software.

The current study may not lead to the conclusion that the software of DEC is not useful for English language learning; but, at least, the findings will hopefully inspire course designers, teachers or lecturers, and other stakeholders in education to become aware of some factors, either internal or external, that could affect the success of learning. This is in line with what Oliver (2002) has warned us that the use of ICT in educational settings, by itself acts as a catalyst for change in language learning. ICT is a must to use because ICTs by their very nature are tools that encourage and support independent learning. That's why future studies on acceptability of ICT-based courseware are still open to be conducted with different subjects and different variables which may lead to different results.

\section{References}

Ajzen, I., \& Fishbein, M. (2000). Attitudes and the attitude-behavior relation: Reasoned and automatic processes. In W. Stroebe, \&. M. Hewstone. (Eds.), European review of social psychology (pp. 1-33). John Wiley \& Sons. https://doi.org/10.1080/14792779943000116

Alharbi, S., \& Drew, S. (2014). Using the Technology Acceptance Model in Understanding Academics' Behavioral Intention to Use Learning Management Systems. International Journal of Advanced Computer Science and Applications, 5(1). https://doi.org/10.14569/IJACSA.2014.050120

Almekhlafi, A. (2006). The effect of Computer-Assisted Language Learning (CALL) on United Arab Emirates EFL school students' achievement and attitude. Journal of Interactive Learning Research, 17(2), 121-142.

Chuan, K. S., \& Chuo, T. W. (2002). Student perception of English learning through ESL/EFL websites. Teaching English as a Second or Foreign Language. TESL EJ.

Davis, F. D. (1989). Perceived usefulness, perceived ease of use, and user acceptance of information technology. MIS Quarterly, 13, 319-339. https://doi.org/10.2307/249008

Davis, F. D., Bagozzi, R. P., \& Warshaw, P. R. (1989). User acceptance of computer technology: A comparison of two theoretical models. Management Science, 35, 982-1003.

Farnaz, V. M. Z., \& Ramazani, M. (2012). Investigation of E-learning acceptance in teaching English language based on TAM model. ARPN Journal of Systems and Software, 2(11).

I-FanLiu. (2010). Extending the TAM model to explore the factors that affect Intentionto Use an Online Learning Community.

Jonassen, D. H., Peck, K. L., \& Wilson, B. G. (1999). Learning with technology. Upper Saddle River, NJ: Merrill Publishing.

Kumar, S., \& Tammelin, M. (2008). Integrating ICT into Language Learning and Teaching: Guide for 
Institutions. Altenberger Straße Linz: Johannes Kepler Universität.

Oliver, R. (2002). The role of ICT in higher education for the 21st century: ICT as a change agent for education. Perth, Western Australia: Cowan University.

\section{Copyrights}

Copyright for this article is retained by the author(s), with first publication rights granted to the journal.

This is an open-access article distributed under the terms and conditions of the Creative Commons Attribution license (http://creativecommons.org/licenses/by/4.0/). 